JESTT Vol. 1 No. 11 November 2014

\title{
PENGARUH HARGA PAKET UMROH, TINGKAT INFLASI DAN KURS RUPIAH PADA DOLLAR TERHADAP PERMINTAAN JASA UMROH DI SURABAYA \\ PERIODE 2011-2013
}

\author{
Masruhatul Abadiyah \\ Mahasiwa Program Studi S1 Ekonomi Islam - Fakultas Ekonomi dan Bisnis - Universitas \\ Airlangga \\ Email: abadiyah21@gmail.com
}

Sri Herianingrum

Departemen Ekonomi Syariah-Fakultas Ekonomi dan Bisnis-Unversitas Airlangga

Email: sriheria@yahoo.co.id

\begin{abstract}
:
There is an interesting phenomena recently that the demand of umroh service increases significantly. This increase is caused by the waiting list for Hajj departure which has to wait for a few years later to take place. This makes the society to take an alternative umroh first which doesn't have to wait for too long. This research aims to find out the effect of umroh package price, inflation rate and rupiah exchange for dollar towards Surabaya umroh service demand during 2011-2013 period. This research uses quantitative approach method and multiple linear regression analysis. The result shows that the umroh package price, inflation rate, and rupiah exchange for dollar variables simultaneously do not have significant effect towards Surabaya umroh service demand during 2011-2013 period. For addition, simultaneously the umroh package price, inflation rate, and exchange rate variables give negative effect towards Surabaya umroh service demand during 2011-2013 period.Umroh service bureaus especially those which reside in Surabaya need to maintain and improve their performances well in order to provide satisfaction and loyalty of the jamaah to increase the demand of umroh service.
\end{abstract}

\section{Keywords : umroh package price, inflation rate, rupiah exchange for dollar}

\section{PENDAHULUAN}

Umroh merupakan salah satu kegiatan ibadah dalam agama Islam. Ibadah ini dilaksanakan dengan cara berkunjung ke Baitullah pada waktu yang tidak ditentukan. Tata cara pelaksanaan umroh dengan berihram dari miqat, kemudian tawaf, sa'i dan diakhiri dengan menggunting rambut dan dilaksanakan dengan tertib. Pelaksanaan umroh lebih sederhana dari pada haji sehingga sering kali disebut haji kecil. Lama umroh sesuai dengan paket yang dipilih oleh jamaah, pada umumnya 9-15 hari di Mekkah dan Madinah.

Fenomena yang menarik akhirakhir ini adalah permintaan jasa umroh atau jumlah jamaah umroh Indonesia yang terus meningkat dari tahun ke tahun. Hal ini terkait dengan kondisi peningkatan perekonomian masyarakat Indonesia yang juga diikuti dengan peningkatan jumlah biro umroh. Hampir $80 \%$ rakyat di Indonesia beragama Islam (Hadi, 2006:6). Permintaan jasa umroh yang meningkatjuga dipengaruhi oleh semakin panjangnya daftar antrean untuk pergi 
menunaikan ibadah haji ke tanah suci. Daftar tunggu naik haji di Jawa Timur mencapai 15 - 18 tahun. Kondisi tersebut bakal memicu tingginya permintaan jasa layanan ibadah umroh.Indonesia setiap tahunnya memberangkatkan jamaah umroh dalam jumlah yang banyak melalui perusahaan travel atau biro perjalanan yang khusus menyelenggarakan perjalanan umroh dan haji.

Seiring dengan berjalannya waktu, jumlah biro umroh di Indonesia setiap tahun semakin meningkat. Tingginya minat untuk berumroh didukung oleh banyaknya iklan-iklan biro umroh yang semakin massif mempublikasikannya baik di media elektronik ataupun media cetak. Hal ini merupakan fenomena yang cukup menggembirakan, setidaknya menunjukkan minat masyarakat dalam aktivitas beragama.Iklan biro umroh biasanya tidak hanya menawarkan ibadah di Mekkah dan Madinah, tetapi juga menawarkan kewilayah negara Islam lainnya seperti Mesir, Turki, Kuwait, Bahrain dll. Disamping itu biro umroh dalam promosinya juga melibatkan tokoh-tokoh agama sebagai pembimbing atau pemandu perjalanan untuk menarik minat jamaah umroh.

Melihat permintaan jasa umroh yang terus meningkat setiap tahunnya menjadikan hal yang menarik untuk diteliti faktor-faktor yang mempengaruhinya, sehingga dapat mengetahui peningkatan permintaan jasa umroh di Indonesia khususnya di Surabaya. Faktor-faktor yang diduga mempengaruhi bisa secara mikro dan makro. Secara makro faktor yang dimungkinkan berpengaruh adalah tingkat harga, tingkat inflasi dan kurs rupiah pada dollar.

\section{Rumusan Masalah}

1. Apakah secara simultan (bersamasama) variabel harga paket umroh, tingkat inflasi dan kurs rupiah terhadap dollar berpengaruh terhadap permintaan jasa umroh di Surabaya periode 2011-2013?

2. Apakah secara parsial (sendiri-sendiri) variabel harga paket umroh, tingkat inflasi dan kurs rupiah terhadap dollar berpengaruh terhadap permintaan jasa umroh di Surabayaperiode 2011 2013 ?

\section{LANDASAN TEORI}

\section{Definisi Umum tentang Umroh}

Fakhruddin (2003:56) Umroh adalah salah satu kegiatan ibadah dalam agama Islam. Hampir mirip dengan ibadah haji, ibadah ini dilaksanakan dengan cara melakukan beberapa ritual ibadah di kota suci Mekkah, khususnya di Masjidil Haram. Tata cara pelaksanaan umroh dengan melakukan perjalanan ke Saudi Arabia dengan melaksanakan beberapa kegiatan yang wajib dilakukan yaitu : Mengerjakan Ihram, Tawaf, Sa'i dan diakhiri dengan Tahalul. Rochim (2010:8) maksud dari umroh adalah datang ke Baitullah untuk melaksanakan ibadah umroh dengan syarat-syarat yang telah ditentukan. Rasjid (2001:275) mendefinisikan umroh sebagai fardu a'in atas tiap-tiap laki-laki atau perempuan, 
sekali seumur hidup, seperti haji. Sutar (2006:166) adapun hukum umroh adalah fardu a'in bagi segenap orang muslim baik laki-laki maupun perempuan.

\section{Teori Permintaan dan Penawaran}

Teori permintaan dan penawaran sebagai dasar untuk menjelaskan adanya permintaan akan jasa biro umroh di Surabaya yang mempengaruhi permintaan atau jumlah jamaah umroh Surabaya, seperti penjelasan sebelumnya bahwa hukum permintaan yaitu ketika harga naik maka permintaan akan menurun, ketika harga turun maka permintaan akan naik. Selanjutnya adalah teori penawaran yang menjelaskan tentang jasa yang dibeli oleh jamaah umroh Surabaya kepada biro umroh di Surabaya, adapun hukum penawaran yakni ketika harga naik maka penawaran akan mengalami kenaikan, begitu juga sebaliknya.

\section{Definisi Teori Permintaan}

Permintaan merupakan keinginan konsumen dalam membeli suatu barang atau jasa pada berbagai tingkat harga selama periode waktu tertentu. Singkatnya permintaan adalah banyaknya jumlah barang atau jasa yang diminta oleh konsumen pada suatu pasar tertentu dengan tingkat harga tertentu pada tingkat pendapatan tertentu dan dalam periode tertentu.

\section{Teori Penawaran}

Terdapatnya permintaan belum merupakan syarat yang cukup untuk mewujudkan transaksi dalam pasar.
Permintaan yang wujud hanya dapat dipenuhi apabila para penjual dapat menyediakan barang-barang yang diperlukan tersebut. Bagaimana tingkah laku penjual dalam menyediakan atau menawarkan barang-barang yang diperlukan oleh masyarakat dipasar serta faktor-faktor yang mempengaruhi produksi dan penawaran barang maupun jasa yang akan dijual.

\section{Definisi Harga}

Kemudian menurut Harini (2008:55) harga adalah vang (ditambah beberapa produk kalau mungkin) yang dibutuhkan untuk mendapatkan sejumlah kombinasi dari produk dan pelayanannya. Menurut Marius (1999:24) harga merupakan jumlah vang yang harus konsumen bayarkan untuk mendapatkan suatu produk maupun jasa. Harga merupakan variabel dari program bauran pemasaran yang mempengaruhi keputusan pembelian konsumen. Payne (2000:171) harga dibuat dengan menambah presentasi mark-up pada biaya atas manfaat-manfaat dalam memakai atau menggunakan suatu produk atau jasa.

\section{Penetapan Harga Dalam Islam}

Ibn Taimiyah dalam Karim (2007:143) menjelaskan mengenai pengaturan tingkat harga oleh pemerintah serta juga memberi perhatian pada monopoli, oligopoli dan monopsoni. Sebagai tambahan dari harga pasar, Ibn Taimiyah membahas konsep-konsep keuntungan yang adil (just profit), upah yang adil (just wage) dan kompensasi 
yang adil (just compensation). Dalam penetapan harga pasar, harga pasar harus terjadi dalam pasar yang kompetitif dan tidak boleh ada penipuan.

\section{Definisi Inflasi}

Nanga (2001:237) menyatakan bahwa inflasi adalah suatu gejala dimana tingkat harga umum mengalami kenaikan secara terus-menerus. Kenaikan tingkat harga umum yang terjadi sekali waktu saja tidaklah dapat dikatakan sebagai inflasi.

\section{Teori Inflasi dalam Perpektif Islam}

Al-maqrizi (1364M-1441M) dalam Karim (2010:140) menggolongkan inflasi dalam dua golongan yaitu : Natural Inflation dan Human Error Inflation.

\section{Natural Inflation}

Sesuai dengan namanya, inflasi jenis ini diakibatkan oleh sebab-sebab alamiah, dimana orang tidak mempunyai kendali atasnya (dalam hal mencegah), Al-Maqrizi mengatakan bahwa inflasi ini adalah inflasi yang diakibatkan oleh turunnya Penawaran Agregatif (AS) atau naiknya Permintaan Agregatif (AD)

2. Human Error Inflation

Human error Inflation dikatakan sebagai inflasi yang diakibatkan oleh kesalahan dari manusia itu sendiri.

\section{Definisi Kurs}

Valuta Asing adalah mata vang yang bukan merupakan alat pembayaran yang sah di suatu Negara. Contoh Dollar di Indonesia, untuk dapat melakukan transaksi dinegara tempat ia berada, ia harus menukarnya dengan vang di pasar valuta asing. Menurut Hadi (1997:15) valuta asing adalah mata vang asing yang difungsikan sebagai alat pembayaran untuk membiayai transaksi ekonomi keuangan internasional dan juga mempunyai catatan kurs resmi pada Bank Sentral.

\section{Tukar Menukar Uang dalam Tinjauan Fiqh} Islam

Menurut Mas'adi (2002:149) menyatakan bahwa Sharf adalah seperti menjual belikan emas dengan emas atau emas dengan perak baik berupa perhiasan maupun mata uang. Praktek jual beli valuta asing (valas), atau penukaran antara mata uang sejenis, seperti yang berkembang saat ini.

Persyaratan yang harus dipenuhi dalam akad Sharf menurut Mas'adi (2002:150) adalah:

1. Masing-masing pihak saling menyerahterimakan barang sebelum keduanya berpisah. Syarat ini untuk menghindarkan terjadinya riba nasi'ah. Jika keduanya atau salah satunya tidak menyerahkan barang sampai keduanya berpisah maka akad sharf menjadi batal

2. Jika ada akad sharf dilakukan atas barang sejenis maka harus seimbang, sekalipun keduanya berbeda kualitas atau model cetakannya

3. Khiyar syarat tidak berlaku dalam akad sharf, karena akad ini sesungguhnya merupakan jual-beli dua benda secara tunai. Sedang khiyar syarat mengindikasikan jual beli secara tidak 
tunai. Berbeda dengan khiyar aib dan khiyar ru'yat. Kedua jenis khiyar yang disebut terakhir ini sesungguhnya melekat dalam setiap akad untuk mrnghindarkan terjadinya gharar. Oleh karena itu masing-masing pihak menggunakan dua jenis khiyar ini didalam akad sharf.

Berdasarkan permasalahan yang telah dirumuskan, tujuan penelitian serta landasan teori yang telah disebutkan sebelumnya, hipotesis yang dapat dirumuskan dalam penelitian ini adalah :

1. Diduga variabel harga paket umroh, inflasi dan kurs rupiah pada dollarsecara simultan memiliki pengaruh signifikan terhadap permintaan jasa umroh Surabaya periode 2011-2013.

2. Diduga variabel harga paket umroh, inflasi, dan kurs rupiah pada dollar secara parsial (sendiri-sendiri) memiliki pengaruh signifikan terhadap permintaan jasa umroh Surabaya periode 2011-2013.

\section{METODOLOGI PENELITIAN}

Penelitian ini menggunakan pendekatan kuantitatif yakni dengan mengadakan pengujian hipotesis, pengukuran data dan pembuatan kesimpulan. Metode yang digunakan pada persamaan regresi dalam penelitian ini adalah dengan metode regresi linier berganda. Untuk metode ini, setiap model persamaan yang digunakan harus mempunyai variabel terikat dan variabel bebas.
Definisi operasional yang digunakan dalam model adalah sebagai berikut :

1. Permintaan Jasa Umroh (Y)

Permintaan jasa umroh (Y) didefinisikan sebagai rata-rata permintaan jasa umroh atau jumlah jamaah Surabaya perbulan yang berangkat umroh melalui beberapa biro umroh yang ada di Surabaya periode 2011-2013.

2. Harga $\left(X_{1}\right)$

Harga $\left(X_{1}\right)$ dalam penelitian ini adalah rata-rata harga paket umroh yang didapat dari biro umroh di Surabaya periode 2011-2013. Harga dalam penelitian ini disamakan dengan mengambil harga paket reguler sembilan hari dan menggunakan fasilitas kelas menengah dengan menggunakan pesawat Lion Air atau sejenisnya.

3. Tingkat Inflasi $\left(X_{2}\right)$

Tingkat Inflasi $\left(X_{2}\right)$ yang digunakan dalam penelitian ini adalah data inflasi bulanan berdasarkan Indeks Harga Konsumen periode 2011-2013.

4. Kurs Rupiah pada Dollar $\left(X_{3}\right)$

Kurs rupiah terhadap dollar $\left(X_{3}\right)$ dalam penelitian ini adalah data kurs jual bulanan nasional periode 2011-2013.

\section{Populasi dan Sampel}

Populasi yang digunakan dalam penelitian ini adalah seluruh jasa biro umroh yang berada di Surabaya baik yang telah mendapatkan izin dari pemerintah atau yang tidak memiliki izin 
dari pemerintah dalam menjalankan bisnis perjalanan jasa biro umroh.

Kriteria sampel yang digunakan dalam penelitian ini adalah jasa biro umroh yang berada di Surabaya dengan syarat kriteria sampel sebagai berikut :

1. Mendapatkan izin operasi dari pemerintah

2. Tergabung dalam asosiasi PPUH (Penyelenggara Perjalanan Umroh dan Haji) tahun 2013

3. Memiliki data harga bulanan

4. Memiliki data sesuai tahun periode penelitian tahun 2011-2013.

5. Biro umroh mengijinkan dalam pengambilan data yang berkaitan dengan penelitian.

\section{HASIL PENELITIAN DAN PEMBAHASAN}

\section{Uji Normalitas}

Uji normalitas digunakan untuk mengetahui apakah suatu data mengikuti sebaran normal atau tidak. Uji normalitas pada penelitian ini dilakukan dengan melihat uji kolmogorov smirnov pada residual. Berikut ini hasil uji normalitas pada residual :

\section{Tabel 4}

Hasil Uji Normalitas

One-Sample Kolmogorov-Smirnov Test

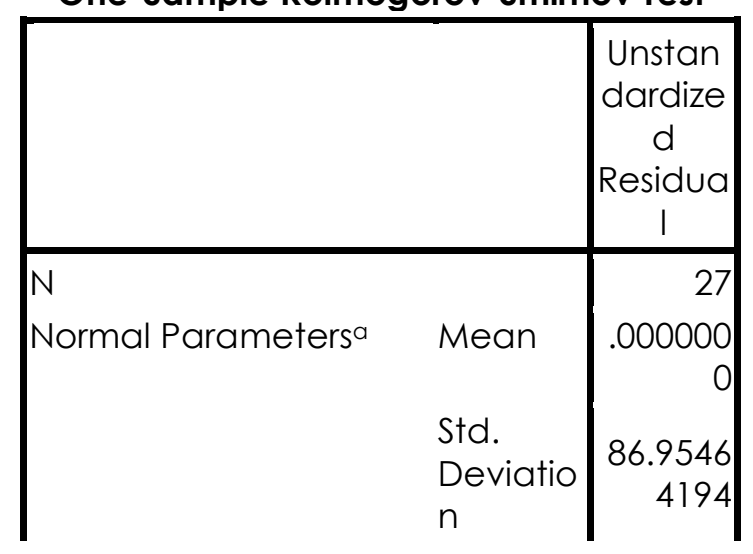

\begin{tabular}{|ll|r|} 
Most Extreme & Absolut & .096 \\
Differences & $\mathrm{e}$ & \\
& Positive & .079 \\
& Negativ & -.096 \\
& $\mathrm{e}$ & .501 \\
Kolmogorov-Smirnov z & & .963 \\
\hline Asymp. Sig. (2-tailed) & &
\end{tabular}

Sumber : Lampiran

Dilihat dari tingkat signifikan yang dihasilkan yaitu 0,963 adalah lebih dari nilai 0,05 maka residual mengikuti distribusi normal, sehingga didapatkan variabel Harga, Inflasi, Kurs dan Permintaan Jasa umroh di Surabaya telah berdistribusi normal.

\section{Uji Heteroskedastisitas}

Uji heteroskedastisitas bertujuan untuk menguji apakah dalam model regresi terjadi ketidaksamaan varians dari residual satu pengamatan ke pengamatan lainnya. Salah satu cara untuk mendeteksi ada atau tidak adanya heteroskedastisitas digunakan uji korelasi Rank Spearman. Adapun hasil uji heteroskedastisitas pada masing-masing variabel adalah :

Tabel 4.5

Hasil Dari Uji Korelasi Rank Spearman

\begin{tabular}{|l|c|c|}
\hline $\begin{array}{c}\text { Variabel } \\
\text { Penelitian }\end{array}$ & $\begin{array}{c}\text { Korelasi Rank } \\
\text { Spearman }\end{array}$ & Sig. \\
\hline Harga & 0,006 & 0,975 \\
$\left(X_{1}\right)$ & $-0,069$ & 0,731 \\
Inflasi $\left(X_{2}\right)$ & 0,037 & 0,856 \\
Kurs $\left(X_{3}\right)$ & & \\
\hline
\end{tabular}

Sumber : Lampiran

Berdasarkan tabel diatas terlihat bahwa antar residual dengan variabel bebas tidak terjadi heteroskedastisitas, dilihat dari tingkat signifikan pada variabel 
variabel Harga $\left(X_{1}\right)$, Inflasi $\left(X_{2}\right)$, Kurs $\left(X_{3}\right)$ melebihi $5 \%$.

\section{Pengujian Gejala Autokorelasi}

Menurut Gujarati (2003) pengujian autokorelasi dimaksudkan untuk menilai serial korelasi antar masing-masing tingkat kesalahan penganggu pada masingmasing periode observasi. Hasil pengujian autokorelasi dapat dilihat pada tabel. Nilai Durbin-Watson (DW Test) akan dibandingkan dengan nilai tabel dengan menggunakan derajat kepercayaan $5 \%$. Bila $d u<d w<(4-d u)$, maka tidak terjadi autokorelasi. Berikut ini hasil uji autokorelasi durbin watson pada variabel Harga $\left(X_{1}\right)$, Inflasi $\left(X_{2}\right)$, Kurs $\left(X_{3}\right)$ sebagai berikut.

\section{Tabel 4.6}

\section{Hasil Dari Uji Durbin Watson}

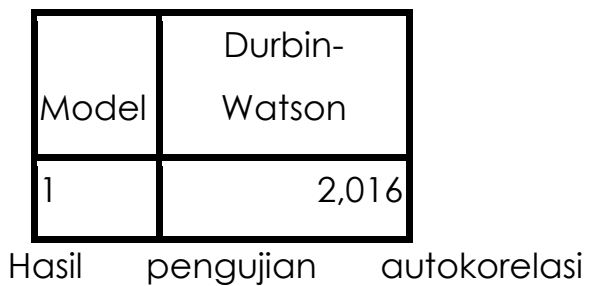

dikatakan tidak terjadi auto jika nilai antara du sampai (4-du) pada tabel nilai du pada jumlah variabel bebas $=3$, dengan $\mathrm{n}$ sebesar 27, nilai DW yang dihasilkan sebesar 2,016 sedangkan nilai dL sebesar 1,16 dan dU sebesar 1,65. Jika dibandingkan dengan nilai $\mathrm{dL}$ dan $\mathrm{dU}$, ternyata nilai DW pada penelitian ini yaitu 2,016 lebih dari 1,16 (dL) sehingga dapat dikatakan tidak terjadi autokorelasi atau asumsi autokorelasi terpenuhi.

\section{Persamaan Regresi Linier}

Adapun hasil pengolahan analisis regresi linier dapat dilihat pada tabel dibawahini :

Tabel 4.7

\section{Persamaan Regresi Linier Berganda}

\begin{tabular}{|l|c|}
\hline Variabel bebas & Koefisien regresi \\
\hline Konstanta & $-46,681$ \\
Harga $\left(X_{1}\right)$ & 0,090 \\
Inflasi $\left(X_{2}\right)$ & 17,112 \\
Kurs $\left(X_{3}\right)$ & 0,027 \\
\hline
\end{tabular}

Sumber : Lampiran

Berdasarkan tabel di atas, maka persamaan yang didapat adalah :

$$
\begin{aligned}
Y= & -46,681+0,090 X_{1}+17,112 X_{2}+ \\
& 0,027 X_{3}
\end{aligned}
$$

Dari hasil persamaan regresi di atas dapat diperoleh penjelasan bahwa (bo) konstanta $=-46,681$. Koefisien regresi untuk variabel Harga $\left(X_{1}\right)=0,090$ artinya, apabila Harga naik satu satuan, maka permintaan jasa umroh akan naik 0,090 satuan. Koefisien regresi untuk variabel Inflasi $\left(X_{2}\right)=17,112$ artinya, apabila Inflasi naik satu satuan, maka permintaan jasa umroh akan naik 17,112 satuan. Koefisien regresi untuk variabel Kurs $\left(X_{3}\right)=0,027$ artinya, apabila Kurs naik satu satuan, maka permintaan jasa umroh akan naik 0,027 satuan.

\section{Uji F (Uji Pengaruh Secara Simultan)}

Hasil uji F dapat digunakan untuk mengetahui pengaruh variabelHarga $\left(X_{1}\right)$, Inflasi $\left(X_{2}\right)$, Kurs $\left(X_{3}\right)$ dan Permintaan Jasa Umroh Umroh (Y). Adapun hasil dari uji $F$ adalah sebagai berikut : 
Tabel 4.8

Hasil Uji F ANOVAb

\begin{tabular}{|l|c|c|c|c|c|}
\hline Model & $\begin{array}{c}\text { Sum of } \\
\text { Squares }\end{array}$ & Df & $\begin{array}{c}\text { Mean } \\
\text { Square }\end{array}$ & F & Sig. \\
\hline $\begin{array}{l}\text { 1Regressi } \\
\text { on }\end{array}$ & 75641.813 & 3 & 25213.938 & 2.950 & $.054 a$ \\
Residual & 196588.854 & 23 & 8547.341 & & \\
Total & 272230.667 & 26 & & & \\
\hline
\end{tabular}

Sumber : Lampiran

Berdasarkan tabel diatas

menunjukkan bahwa nilai Fhitung sebesar 2,950 dengan tingkat signifikan lebih besar dari $5 \%$ yaitu sebesar 0,054 . Hal ini berarti variabel Harga $\left(X_{1}\right)$, Inflasi $\left(X_{2}\right)$ dan Kurs $\left(X_{3}\right)$ tidak berpengaruh secara simultan terhadap Permintaan Jasa Umroh (Y).

\section{Uji † (Uji Pengaruh Secara Parsial)}

Hasil uji † dapat digunakan untuk mengetahui variabel Harga $\left(X_{1}\right)$, Inflasi $\left(X_{2}\right)$ dan Kurs $\left(X_{3}\right)$ secara parsial terhadap Permintaan Jasa Umroh (Y). Adapun hasil dari uji $t$ adalah sebagai berikut :

\section{Tabel 4.9}

\section{Hasil Uji $\uparrow$}

\begin{tabular}{|l|c|c|}
\hline Variabel bebas & t-hitung & Sig. \\
\hline Konstanta & $-0,238$ & 0,814 \\
Harga $\left(X_{1}\right)$ & 1,298 & 0,207 \\
Inflasi $\left(X_{2}\right)$ & 1,286 & 0,211 \\
Kurs $\left(X_{3}\right)$ & 1,269 & 0,217 \\
\hline
\end{tabular}

Sumber : Lampiran

Berdasarkan tabel di atas terlihat bahwa variabel bebas menghasilkan tingkat signifikan lebih dari $5 \%$ dengan demikian dapat disimpulkan bahwa Harga $\left(X_{1}\right)$, Inflasi $\left(X_{2}\right)$ dan kurs $\left(X_{3}\right)$ tidak berpengaruh secara parsial terhadap Permintaan Jasa Umroh (Y).

\subsubsection{Nilai Koefisien Determinasi $\left(R^{2}\right)$}

Guna mengetahui besar kontribusi variabel Harga $\left(X_{1}\right)$, Inflasi $\left(X_{2}\right)$ dan kurs $\left(X_{3}\right)$ terhadap Permintaan Jasa umroh ( $Y$ ) dapat dilihat dari nilai $R$ square yaitu :

Tabel 4.10

Koefisien Korelasi dan Determinasi Model Summaryb

\begin{tabular}{|l|c|r|r|r|}
\hline Model & $\mathrm{R}$ & $\begin{array}{c}\mathrm{R} \\
\text { Square }\end{array}$ & $\begin{array}{c}\text { Adjuste } \\
\mathrm{d} R \\
\text { Square }\end{array}$ & $\begin{array}{c}\text { Std. Error of } \\
\text { the } \\
\text { Estimate }\end{array}$ \\
\hline 1 & $.527 \mathrm{a}$ & .278 & .184 & 92.45183 \\
\hline
\end{tabular}

Sumber : Lampiran

Koefisien determinasi digunakan untuk menghitung besarnya pengaruh atau kontribusi variabel bebas terhadap variabel terikat. Dari analisis pada tabel diatas diperoleh hasil nilai $R$ square (koefisien determinasi) yang dihasilkan sebesar 0,278 yang berarti bahwa Harga $\left(X_{1}\right)$, Inflasi $\left(X_{2}\right)$ dan kurs $\left(X_{3}\right)$ mampu menjelaskan variabilitas dari Permintaan Jasa Umroh (Y) sebesar 27,8\% dan sisanya sebesar $72,2 \%$ dijelaskan oleh variabel lain yang tidak dibahas pada penelitian ini.

\section{Pembahasan}

\section{Pengaruh Harga Paket Umroh Terhadap} Permintaan Jasa Umroh di Surabya

Dari hasil perhitungan diperoleh nilai $t$ test sebesar 1,298 dengan nilai signifikansi sebesar 0,207 > 0,05, Maka dapat kita lihat hasil uji $†$ ini, tidak sesuai dengan hipotesis yang menyatakan bahwa diduga harga paket umroh berpengaruh terhadap permintaan jasa umroh, maka hipotesis pada penelitian ini ditolak. Akan tetapi apabila melihat pada teori permintaan menurut Zamroni 
(2009:11) yang menyatakan bahwa "...ketika harga mengalami kenaikan maka permintaan akan menurun...", apabila melihat pada pengaruh harga yang tidak signifikan terhadap permintaan jasa umroh maka hal ini sesuai dengan teori permintaan, dalam teori permintaan dikatakan ketika harga naik maka permintaan akan menurun, tetapi pada kenyataannya dalam penelitian ini ketika harga umroh mengalami kenaikan setiap tahunnya permintaan tidak mengalami penurunan tetapi semakin menigkat. Kenyataan ini merupakan hal yang menggembirakan karena pada kenyataannya jamaah tidak menjadikan variabel harga paket umroh, tingkat inflasi dan kurs rupiah pada dollar sebagai penentu utama dalam pengambilan keputusan menunaikan ibadah umroh, namun karena mempunyai niat ikhlas untuk beribadah karena Allah SWT.

\section{Pengaruh Inflasi Terhadap Permintaan}

\section{Jasa Umroh di Surabaya}

Dari hasil perhitungan diperoleh nilai $t$ test sebesar 1,286 dengan nilai signifikansi sebesar 0,211> 0,05. Maka dapat kita lihat hasil uji $t$ ini, tidak sesuai dengan hipotesis yang menyatakan bahwa diduga Inflasi berpengaruh terhadap permintaan jasa umroh, maka hipotesis pada penelitian ini ditolak. Akan tetapi apabila melihat pada teori Keynes yang dinyatakan oleh Boediono (1982:163164) "... adanya kenaikan harga-harga berarti bahwa sebagian dari rencanarencana pembelian barang dan jasa dari golongan-golongan tidak bisa terpenuhi...". Apabila melihat pada pengaruh inflasi yang tidak signifikan terhadap permintaan jasa umroh maka hasil penelitian ini sesuai dengan teori Keynes diatas, dalam teori Keynes dikatakan ketika harga naik maka sebagian dari rencana-rencana pembelian barang dan jasa tidak bisa dipenuhi, tetapi pada kenyataannya dalam penelitian ini ketika inflasi mengalami kenaikan setiap tahunnya permintaan jamaah umroh terpenuhi atau mengalami peningkatan.

Inflasi tidak mempengaruhi konsumen menengah keatas dalam hal pembelian konsumsi, inflasi mempengaruhi konsumsi pada konsumen tingkat menengah kebawah dikarenakan harga secara keseluruhan mengalami peningkatan, pada hasil penelitian ini yang mengatakan bahwa inflasi tidak mempengaruhi permintaan jasa umroh memberikan kesimpulan bahwa masyarakat surabaya memiliki pendapatan menengah keatas apabila melihat pada hasil penelitian ini pada periode 2011-2013.

\section{Pengaruh Kurs Rupiah Pada Dollar Terhadap Permintaan Jasa Umroh di Surabaya}

Dari hasil perhitungan diperoleh nilai $t$ test sebesar 1,269 dengan nilai signifikansi sebesar 0,217>0,05. Maka dapat kita lihat hasil uji $t$ ini, tidak sesuai dengan hipotesis yang menyatakan bahwa diduga kurs rupiah pada dollar 
berpengaruh terhadap permintaan jasa umroh, maka hipotesis pada penelitian ini ditolak. Akan tetapi apabila melihat padateori Nordhaus (2004:308-309) yang menyatakan "...efek perubahan kurs (kenaikan) mengakibatkan penurunan pembelian barang dan jasa...", apabila melihat pada pengaruh kurs rupiah pada dollar yang tidak signifikan terhadap permintaan jasa umroh maka sesuai dengan teori Nordhaus diatas, dalam teori Nordhaus dikatakan efek kenaikan kurs mengakibatkan pembelian barang dan jasa, tetapi pada kenyataannya dalam penelitian ini ketika kurs mengalami kenaikan setiap tahunnya permintaan jasa umroh juga mengalami peningkatan.

Pengaruh Variabel Harga Paket Umroh, Inflasi dan Kurs Rupiah pada Dollar terhadap permintaan jasa umroh di Surabaya

Berdasarkan uji F, terlihat pada tabel 4.7 dapat diketahui bahwa Fhitung sebesar 2,950 dengan tingkat signifikansi 0,054 . Dikarenakan nilai signifikansi $F$ adalah lebih besar dari $a=0,05$ berarti tidak bengaruh signifikan secara simultan dari ketiga variabel independen $\left(X_{1}, X_{2}, X_{3}\right)$ terhadap permintaan jasa umroh Surabaya yang menjadi obyek penelitian tahun 2011-2013. Dan berdasarkan pada tabel 4.9 uji † terlihat bahwa variabel bebas menghasilkan tingkat signifikan lebih dari $5 \%$ dengan demikian dapat disimpulkan bahwa Harga $\left(X_{1}\right)$, Inflasi $\left(X_{2}\right)$ dan kurs $\left(X_{3}\right)$ tidak berpengaruh secara parsial terhadap Permintaan Jasa Umroh (Y).

Hasil ini menunjukkan bahwa penggabungan variabel independen yaitu Harga Paket Umroh, Tingkat Inflasi dan Kurs Rupiah pada Dollar tidak relevan digunakan untuk memprediksi permintaan jasa umroh khususnya di Surabaya pada tahun 2011-2013. Seperti pada penjelasan sebelumnya hal ini menggembirakan karena variabel makro seperti harga, inflasi dan kurs tidak dijadikan penentu oleh jamaah dalam melakukan umroh melainkan niat karena Allah SWT.

\section{SIMPULAN DAN SARAN}

\section{Simpulan}

Berdasarkan hasil analisis dan pengujian dalam penelitian Pengaruh Harga Paket Umroh, Tingkat Inflasi dan Kurs Rupiah pada Dollar Terhadap Permintaan Jasa Umroh di Surabaya Periode 20112013, maka diperoleh kesimpulan sebagai berikut :

1. Variabel harga umroh $\left(X_{1}\right)$ tidak berpengaruh secara signifikan terhadap permintaan jasa umroh di Surabaya periode 2011-2013.

2. Variabel tingkat inflasi $\left(X_{2}\right)$ tidak berpengaruh secara signifikan terhadap permintaan jasa umroh di Surabaya periode 2011-2013.

3. Variabel kurs rupiah pada dollar $\left(X_{3}\right)$ tidak berpengaruh secara signifikan terhadap permintaan jasa umroh di Surabaya periode 2011-2013.

4. Variabel harga paket umroh, tingkat inflasi dan kurs rupiah pada dollar ( $X_{1}$, 
$X_{2}$ X3) secara simultan tidak berpengaruh secara signifikanterhadap permintaan jasa umroh di Surabaya periode 2011-2013.

5. Kenyataan ini merupakan hal yang sangat menggembirakan karena ternyata jamaah umroh tidak menjadikan hal-hal seperti harga, inflasi dan kurs sebagai penentu menunaikan ibadah umroh melainkan karena panggilan agama Allah SWT.

\section{Saran}

Saran yang direkomendasikan setelah penelitian Pengaruh Harga Paket Umroh, Tingkat Inflasi dan Kurs Rupiah pada Dollar Terhadap Permintaan Jasa Umroh Surabaya Periode 2011-2013 adalah sebagai berikut:

1. Untuk pihak biro umroh secara umum Dikarenakan variabel harga, inflasi dan kurs tidak berpengaruh terhadap permintaan jasa umroh, maka dimungkinkan terdapat variabel lain yang mempengaruhi permintaan jasa umroh seperti pendapatan masyarakat yang meningkat (income), daftar tunggu berangkat haji (waiting list), cita rasa atau selera (taste) dan variabel lainnya. Biro umroh perlu meningkatkan manajemen dan kinerja yang lebih baik guna memberikan kepuasan dan loyalitas jamaah serta untuk meningkatkan permintaan jasa umroh.

2. Untuk penelitian selanjutnya Saran kepada peneliti yang akan datang, karena penelitian ini hanya menggunakan tiga variabel, maka sebaiknya peneliti yang akan datang menggunakan lebih banyak variabel agar didapatkan hasil penelitian yang lebih komprehensif.

\section{DAFTAR PUSTAKA}

Fakhrudin. 2008. Manasik Haji dan Umroh. Surabaya : PT Pustaka Tiga.

Gujarati, Damodar. 2003. Basic Econometrica. New York : The Mc.Graw Hill Company, inc.

Hadi A. 2006. Indonesia dan Problema. Jakarta : Tunggal Samudera.

Karim Adiwarman A. 2010. Ekonomi Makro Islami .Edisi Kedua. Jakarta :PT Raja Grafindo Persada.

\section{Ekonomi Mikro}

Islami. Edisi Ketiga. Jakarta :PT Raja Grafindo Persada.

Marius P. 1999. Dasar-Dasar Pemasaran. Cetakan Pertama. Jakarta.

Mas'adi A. Ghufron. 2002. Figh Muamalah Konstektual. Jakarta: PT Raja Grafindo.

Nanga, Muana. 2001. Makroekonomi:Teori, Masalah dan Kebijakan. Jakarta: : Raja Grafindo Persada.

Payne, Adrian. 2000. Pemasaran Jasa. Yogyakarta : Penerbit Andi Yogyakarta.

Pustaka LP3ES Indonesia.

Raja Grafindo Persada.

Rochim M. 2011. Bimbingan Umroh dan Haji Lengkap. Jakarta : Penerbit Erlangga. 
JESTT Vol. 1 No. 11 November 2014

Sutar. 2006. Tuntunan Praktis Ibadah Haji dan Umroh. Surabaya : Penerbit dan Percetakan Offset Indah. 